\title{
Challenges to Urban Housing Policies Implementation Efforts: The Case of Nairobi, Kenya
}

\author{
Collins Ouma Agayi ${ }^{1}$, Özer Karakayacı $2 \odot$ \\ ${ }^{1}$ PhD student, Faculty of Architecture and Design, Konya Technical University, Konya, Turkey. (Principal contact for editorial \\ correspondence), Email: agaiagayi@gmail.com \\ 2 Assoc. Prof. Dr., Faculty of Architecture and Design, Konya Technical University, Konya, Turkey. Email: \\ karkayaci@gmail.com
}

\begin{abstract} Purpose

The arrival of native African communities from rural Kenya looking for opportunities led to population growth. Nairobi, therefore, has rapidly urbanized and sprawled $18 \mathrm{~km} 2$, and $688 \mathrm{~km} 2 \mathrm{in}$ 1900, and 1963 respectively. With population growth, housing demand has surpassed supply resulting in the housing crisis. The aim of this paper is to a) examine the policy and legal efforts put forward to address the housing problem in Nairobi, b) discuss the challenges to the urban housing policies implementation efforts, and c) make suggestions based on the findings of social, economic and infrastructural impacts of the intervention measures.
\end{abstract}

Design/Methodology/Approach

The research establishes that government efforts to address the housing problem through measures like urban migration restriction, employer housing, housing schemes, slum demolitions, and slum upgrading have not been successful due to challenges of land security tenure, gaps in policy enforcement, and compliance, insufficient public participation among others.

\section{Findings}

The paper makes appropriate suggestions to reform the policy approaches by focusing not only on housing aspects but economic, and land tenure reforms, and the extent of public involvement.

\section{Research Limitations/Implications}

The study analyses secondary sources including research articles, theses, and governments whose data were collected through primary methods like interviews, field observation, and administration of questionnaires. It, therefore, limited the findings in case of Nairobi.

\section{Practical Implications}

The study contributes to recommend that provision of the basic services be carried out in the slums alongside and economic empowerment programs to relieve the residents of financial poverty. Slum upgrading programs should therefore seek to impact the socio-economic lives of the slum dwellers.

Originality/Value

This study explores past and present efforts by different regimes and non-governmental organizations to give an answer to the housing crisis in Kenya. and the subsequent development of slums and informal settlements.

Keywords: Citizens participation, housing demand, housing crisis, housing policies, informal settlements 


\section{INTRODUCTION}

As the world's population is growing, so is the rate of urbanization. The recent figures by the United Nations project that by 2050, approximately $66 \%$ of the world population will be residing in urban areas, an increase from the 54\% figures provided in 2014 (UN, 2014). Despite positive influences attributed to urbanization like economic growth, negative outcomes like inequality, poverty and slum development could also be linked to it (Sulemana, Nketiah-Amponsah, Codjoe, \& Andoh, 2019). Agayi and Karakayacı (2020) also attribute the rising land prices and demand for housing in urban areas to rapid urbanization, therefore, affecting the affordability and access of housing by low- and middle-income earners. This is the case in Nairobi where at least $50 \%$ of the residents live in informal settlements that account for only $5 \%$ of the total residential land (Amnesty International, 2009). The same is reflected in homeownership and demand for housing in Nairobi with the high-income earners having a 60\% surplus while the low and middle-income earners have a housing deficit of 95\% (Presidency, 2017). Despite the efforts by the various regimes and organizations to find solution to housing and slums problems in Nairobi through measures like restriction of urban movement, housing of employees, allocation of sites for self-help housing construction to African and forceful eviction and demolition of slums, the number of slums and informal settlement continue to grow pointing to a weakness in the efforts (Everett, 2001).

In case of Nairobi (the capital city of Kenya) and Kibera (the biggest slum in Nairobi), this study explored past and present efforts by different regimes and non-governmental organizations to give an answer to the housing crisis in Kenya and the subsequent development of slums and informal settlements. The study did not only reveal the inhuman and harmful (Syagga, 2011), discriminative and segregative (Home, 2012), and less participatory (Anderson \& Mwelu, 2013) natures of the methods adopted by the government to address the housing challenges, but also the legal, legitimacy and logistical challenges in the implementation.

\section{METHODOLOGY AND DEFINITION OF THE CASE STUDY AREA}

The high population growth rate in Kenya coupled with the desire for better living conditions forced many to look for opportunities in the urban areas of Kenya, leading to rapid urbanization. While the ruralurban migration is not new as it started in the colonial period, it became so rampant after easing of the restriction to movement by Africans at independence in 1963. The rapid urbanization caused the housing crisis especially in Nairobi as there was no adequate house to accommodate African 'immigrants. Lack of comprehensive housing policy for Africans exacerbated the crisis with many opting to set up informal settlements. The mushrooming of slums and the inability of the government to provide decent and affordable housing to citizens is what led to housing 
challenges in Kenya. This study examined efforts put forward both in the colonial period and after independence to address the housing problem in Kenya. In the pre-independence era, the study examined academic, government and institutional reports, policies and research work to understand the historical context of African housing problems which was racial in nature and the interventions put forward to address them. After independence, the housing problem shifted from racial to a class problem with many low- and middle-income earners unable to afford houses, preparing grounds for slums formation. The research, therefore, relied on secondary data materials like policies, regulations, academic research, government reports, and non-governmental organization research outputs to identify and assess present interventions like slum upgrading. By examining these sources of data, the research also established the weakness of the intervention efforts by the government.

The study focused on Nairobi, the capital city of Kenya which received the highest numbers of African 'immigrants' being the central administrative unit of the country and the settlement of Asian railway workers and Europeans during the construction of the railway line. Most of the housing policies formulated by the colonial government were thus intended to address the housing problem in Nairobi. The latest efforts have, however, focused on upgrading slums in urban areas. Poor urban policies coupled with a housing deficit have seen many people move to informal settlements where the cost of living is slightly affordable compared to the formal settlements. The living condition in the slums is however very wanting due to the lack of basic services need for day to day life of human beings. Corburn (2013) best describes the social, economic, and infrastructural deprivations in Kenyan slums that have been neglected and denied services due to their informal and illegal status. In the book "Healthy City Planning: From Neighbourhood to National Health Equity", Mathare Slums in Nairobi is described as having many socio-economic and infrastructural deficiencies including a) insufficient water and sewage services, b) inaccessible earth roads without sidewalks, c) tin-roofed mud-surface structures, d) constant power outages, e) insecurity from gangs like "Mungiki" who frequently blackmail and threaten slum residents, and who are alleged to have conducted atrocities in Mathare slum by beheading and chopping off legs of slum residents following a disputed presidential election of 2007, f) high child mortality rate with one in every five children dying before reaching the age of five, g) $40 \%$ of children are out of schools, h) twothirds of girls are alleged to engage in premarital sexual activities to meet the daily needs, and i) open defecation due to lack of enough latrines.

By focusing on government efforts to address the sprawling problems of the informal settlement in Kenya, this study has examined two of such programs; Kenya Slum Upgrading Program (KENSUP) and Kenya Informal Settlements Improvement Programs (KISIP) and the extent to 
which they were successfully applied in Kibera (the biggest slum in Nairobi). Kibera, which has a total population of 185,777 according to 2019 population statistics, is located just 5 kilometers away from the Nairobi city center (GOK, 2019a). Ogundele (2014) describes Kibera as the biggest slum in the country. The slum has 12 villages including Gichinjio, Kisumu Ndogo, Mashimoni, Silanga, Makina, Soweto East, Kianda, Raila, Lindi, Soweto West, Laini Saba and Gatuikira (MacDonald, 2014). However, the study on slum upgrading efforts focused on Soweto East village where the pilot project was initiated.

\section{EFFORTS TO ADDRESS THE HOUSING PROBLEMS IN KENYA}

Efforts to address the housing, and slums and informal settlements' proliferation problems are not new as they were started by the colonial government through measures aimed at controlling land ownership, settlement, labor, and movement of Africans in the urban areas especially Nairobi. The post-independent governments in Kenya later adopted different strategies in light of rapid urbanization, slum proliferation, and increasing housing prices. The various methods used at different eras and periods to address the housing problems in Kenya include; Use of pass laws to prevent African urbanization, requiring employers to host their workers (mainly Africans), Encouraging selfaccommodation among Africans by allocating them settlement spaces in the urban areas, slum demolition and evictions, slum upgrading and through legal and policy frameworks.

\section{Restricting African Urban Migration through Pass Laws}

The colonial government sought to control urbanization in Kenya through a series of legal measures that were aimed at preventing or controlling the movement of Africans into and within towns. This was done through the enactment of laws that targeted the Africans and restricted any urban land ownership, guided employment, authorized eviction, outlined housing for Africans, etc. Restricting the number of Africans migrating to the towns was implemented through the 1930 Public Health Act and the Vagrancy Acts of 1922 ostensibly to ensure the safety and health of the Europeans in the city. However, as pointed out by Otiso (2005), the Public Health Act was the basis for racial residential segregation in urban areas while the Vagrancy Act was used to ensure European dominance in urban areas by controlling the urban growth of non-white populations especially Africans. In accordance with the Vagrancy Act, anyone without a kipande (identification card) could be detained in prison or repatriated from the urban areas (Home, 2012). Although discriminatory, these pass laws regulated the rate of urbanization in Kenya thus preventing housing crisis and development of slums as the few who were allowed in the towns got some forms of accommodation. Though not very common, rural-urban migrations restriction as a means of regulating population growth in urban areas has been practiced in other countries. Au and Henderson (2006) 
describe how China attempted to restrict migration to urban areas through "the hukou system" which is similar to an internal passport system detailing an individual's local citizenship and entitlements like housing, public health care, public education among others for legal residents in a city while denying migrants the services. Applying the Hukou system and the policy of "incomplete Urbanization", the government denied 800 million migrants the right to settle in the city by not extending to them the most basic services (Chan and Buckingham 2008).

\section{Employee Housing Strategy}

Solving the housing problem in the colonial period was also done by enacting laws ensuring that employers provide housing to their employees. This was done through the enactment of Employment of Servants Ordinance that compelled employers (European and Asians) to provide proper housing to their employees at their places of work or rent a house for them (Hay \& Harris, 2007; Obudho \& Aduwo, 1989). In instances where the servants were not able to return to their homes after work or not able to obtain proper housing close to their working places, it was the responsibility of the employer to house the employee (Home, 2012). Many Africans working for Railways (biggest employer of Africans) were therefore housed in single room timber-frame structures without water and electricity while those working for Europeans and Asians were housed in the same plots in servant quarters, usually a single room for unmarried men as shown in Figure 1.

Figure 1. Kenya Uganda Railways dwelling for an Asian staff complete with African Servants Quarter in 1927 along Desai Road. (Barnow et al., 1983 cited by Hay \& Harris, 2007)
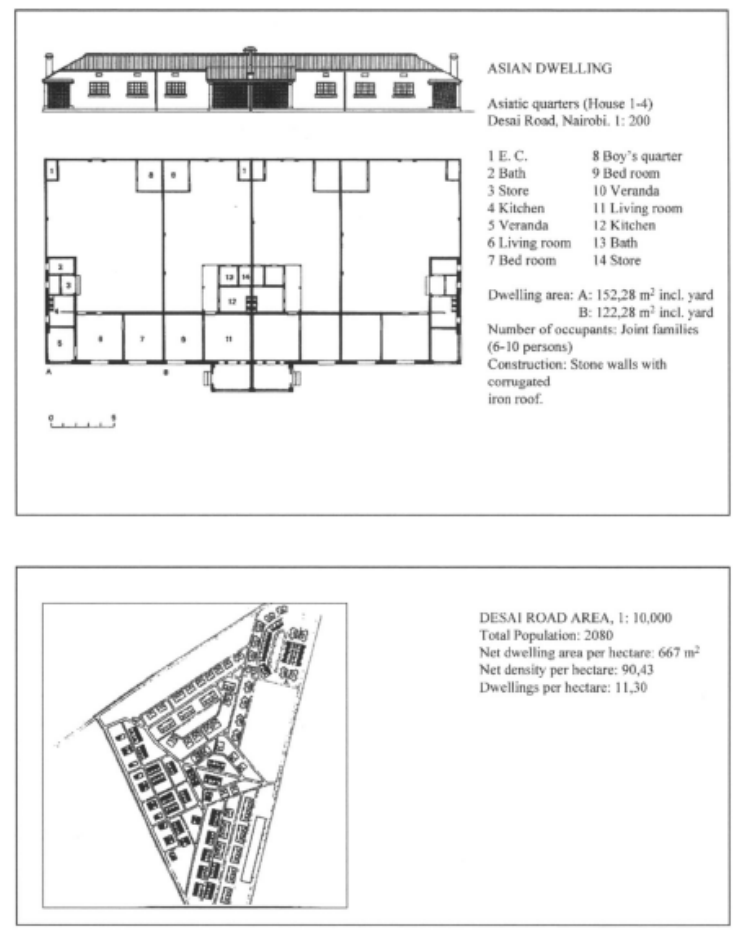
Obudho and Aduwo (1989) attribute lack of a comprehensive housing policy to cater for the housing needs of Africans to their status in the city as temporary migrants who were meant to provide cheap labor. This strategy didn't come to fruition as many employers failed to comply with the requirement to house their employees. For example, in 1939, while the number of legitimate African workers in Nairobi was 40,000, the number of houses available to accommodate the African employees was only 9,000 (Ogilvie, 1946).

\section{Self-Accommodation through Self-Help Housing Schemes.}

The inability of the employers to house all African workers and the desire by the government to relieve itself of the housing burden made the government rethink its strategy of banning property ownership by Africans. To enable Africans to build and own houses in the towns, the government, therefore, encouraged the provision of plots to Africans for housing construction which led to the development of the first self-help African housing schemes Pumwani and Shauri Yako estates in Nairobi (Obudho \& Aduwo, 1989). The lands allocated for African housing development was separate from the areas of settlements by other races as the colonial government continued with its racial residential segregation policy. The residentials were thus divided into African locations, the hilly areas for Europeans and the Asian 'Bazaar' area meant for the Indians.

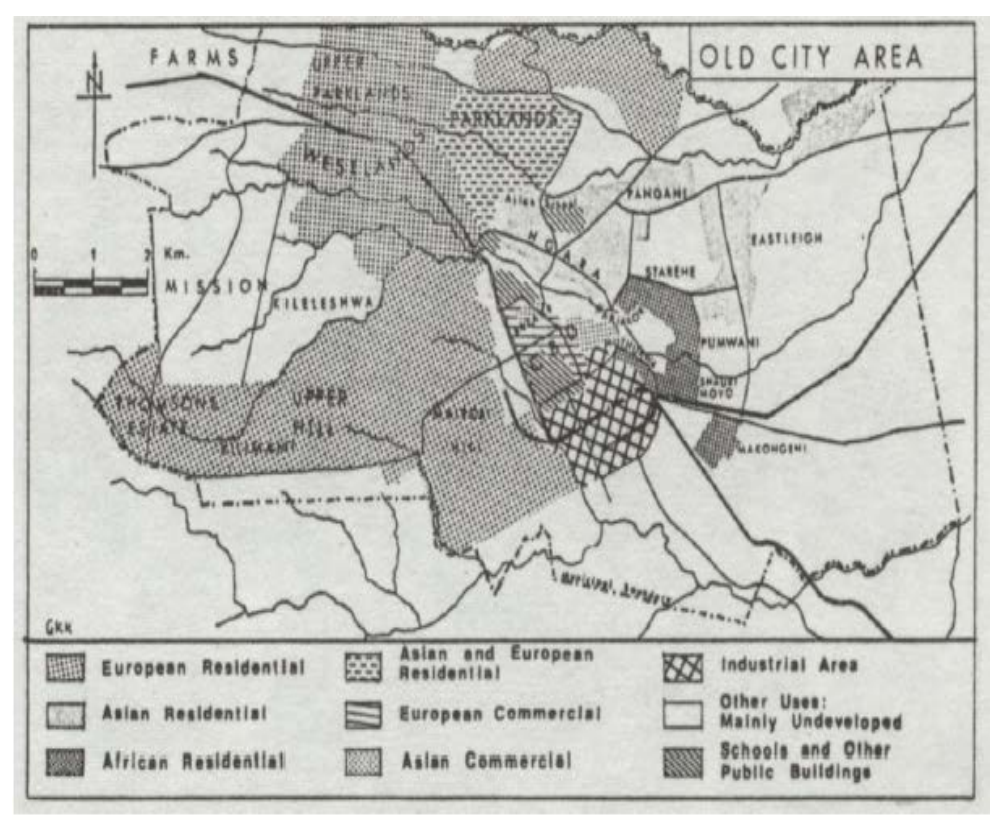

Figure 2. Racial segregation in 1939. (Kingoriah, 1983)

Besides the racial residential segregation, Otiso (2005) points out that the residential places allocated to Africans were very unpleasant such as next to sewerage plants and many Africans couldn't afford housing due to acute urban housing shortage in the African locations. Many, therefore ended up living on streets, under verandas, in shacks and overcrowded rooms. The Inadequacy of urban housing led to the 
development of first slums in Nairobi in the1940s and located next to major employment areas, with some of the major slums in Nairobi like Mathare and Kibera having been established at that time (Obudho \& Aduwo, 1989).

\section{Forceful Slum Evictions and Demolition.}

Amnesty International (2009) found that more than 50\% of Nairobi's population, live in informal settlements occupying less than $5 \%$ of the residential land and less than $1 \%$ of the total land area. This situation is not unique to Kenya, indeed, approximately 59\% of the sub-Saharan African population lives in slums and this is projected to increase as the African urban population is expected to reach 1.2 billion by 2050 (UNHabitat, 2016). Syagga (2011) describes the conditions in slums as lacking clean water, having poor sanitation, overcrowded, lack land tenure security, thus, exposing the slum dwellers to arbitrary evictions. Slum management in Kenya as a way of addressing the housing challenges started in 1895 when Kenya became a British protectorate. Though still applicable today, slum demolition and evictions to create spaces for urban development was a common approach to slum development from 1895 until the 1970s (Syagga, 2011). Lack of alternative accommodation for the evicted slum residents caused them to move to other parts of the towns and reestablish slums. Therefore, the more the government demolished slums, the more the new slums were formed.

Informal settlements formation was more rampant in Nairobi than other towns during colonial periods. The Railways was the major source of employment to most Africans whom they housed according to the requirement of Employment of Servants Ordinance (Hay \& Harris, 2007). Almost every other person not housed by Railways was considered unwanted or surplus labor and could effectively be detained or deported back to the native lands under the Vagrancy Act of 1922. The government attempted to solve the housing shortage by the construction of the first housing estate for Africans (Kariokor) in 1929 in Nairobi. Insufficient financial allocation for African housing compared to their European counterparts $(£ 40,000$ for Africans and $£ 586,430$ for Europeans accommodation) in 1930 coupled with the increasing number of local natives moving to Nairobi, led to construction of temporary structures (informal settlements) in 'Kariokor' by Africans without proper sanitation and clean water (Macharia, 1992). The First demolition of African settlement was conducted in 'Kariokor' in 1931 through the 1930 Public Health Act. A total of 120 shacks were demolished on the ground of poor sanitation and lack of clean water and 3,375 Africans convicted of vagrancy (Macharia, 1992). According to Mitullah (1993), the policy of slum demolitions was also applied in In 1938. This was an attempt by the colonial government to clear Nairobi off the illegal settlements, 
especially in places occupied by Africans. This led to the demolition of Pangani estate (an old African settlement in Nairobi) in 1938.

Slum eviction and demolition policy didn't stop with the achievement of independence. In fact, the National Housing Policy of 1966/67 was unambiguous in calling for slum clearance as a housing strategy (ROK, 2004). The eviction and demolition strategies continued in the 1970s and 80s with no alternative settlements offered and with the decision being taken centrally without the involvement of the affected residents (Wafula, 2004). Lack of compensation to affected households and the failure to provide alternative settlements caused the affected households to find other places where they reestablished the slums. Therefore, whereas the goal of slum clearance has been to get rid of the slums, it has resulted into further proliferation (Everett, 2001).

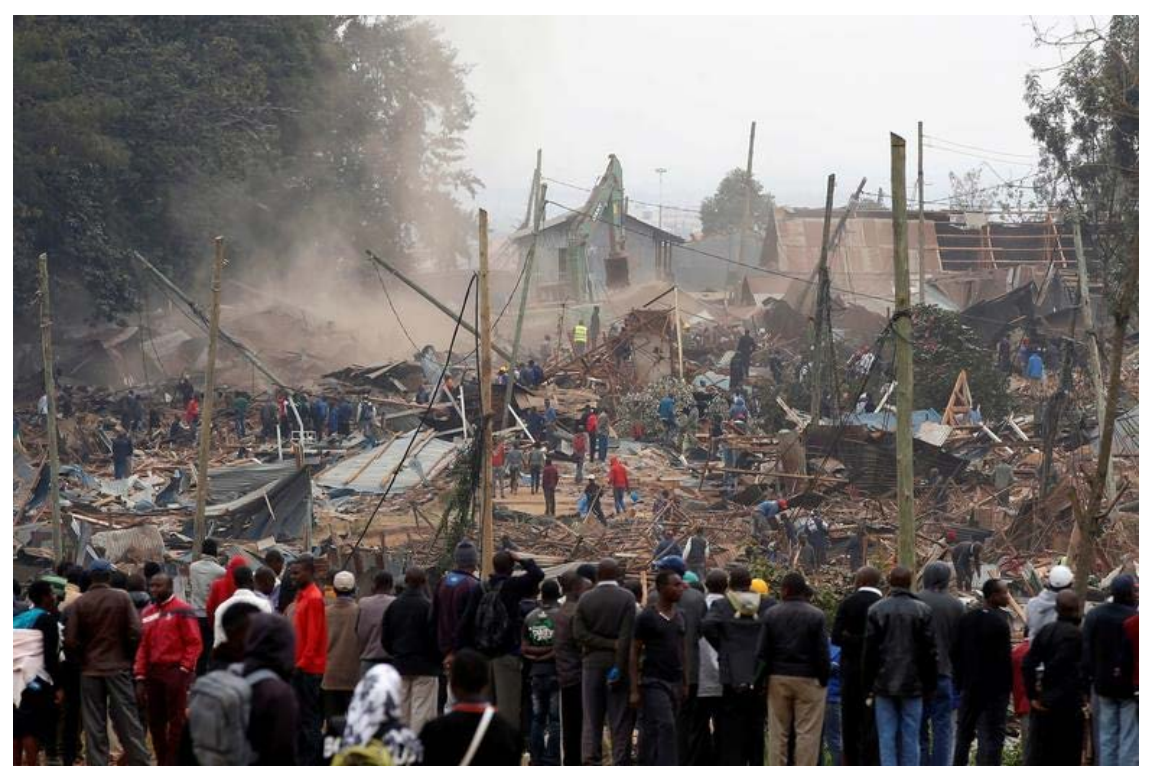

Slum evictions and demolitions are carried out for many reasons. Other than housing purposes, most slum evictions are aimed at improving slum infrastructures, urban resettlement programs, and land expropriation for public use (e.g. roads, railways, schools), urban redevelopment and for speculation purposes usually initiated by private developers (Otiso, 2002). Due to international pressure and the rise of civil rights groups in 1980s, the government has shifted away from forceful evictions and demolitions which were harmful to lives, properties and sources of livelihood, the new methods have since been adopted including the need to improve the conditions in slums through multi-lateral findings (Syagga, 2011).

\section{Slum Upgrading Programs}

Many governments, international development agencies, and local authorities tend to respond to urban informalities like slums through either demolition or slum upgrading (Muchadenyika \& Waiswa, 2018). The inhuman nature and the levels of destruction to properties
Figure 3. Kibera slum demolition to create room for road construction. (News from Reuters dated 2018) 
associated with demolition have drawn international concerns and condemnations thus making it a less popular strategy (Kamete, 2009). Slum upgrading, on the other hand, improves the condition of the slums with very minimum cases of displacement to residents involved (Minnery et al., 2013). Contrary to slum demolition that delegitimizes the slum, slum upgrading integrates the slums into the city while improving the conditions in the slum and formalizing its existence (Olthuis, Benni, Eichwede, \& Zevenbergen, 2015). The upgrading process targets the improvement of physical, social, economic, environmental and organizational aspects of the slum and integrates various actors like citizens, authorities, businesspeople among other stakeholders (UN-Habitat, 2003).

In Kenya, slum upgrading is being conducted through two major initiatives: Kenyan Slum Upgrading Programme (KENSUP) and Kenya Informal Settlement Improvement Project (KISIP). Both initiatives aim at improving the conditions of those living and working in the slum areas without displacing the residents (Muraguri, 2011). These two initiatives were a response to the continued proliferation of the slums in Kenyan towns, with the government records indicating that for every three Kenyans, one lived in slums and informal settlements in 1999. This figure was projected to rise to $50 \%$ by 2015 (GOK, 2010a). Kenyan Slum Upgrading Programme (KENSUP) was initiated by the government of Kenya in collaboration with the UN-Habitat in 2004 to among other objectives improve slums' social and physical infrastructures, housing conditions, address the land tenure security issues among slum dwellers and to empower the slum residents through income-generating
activities (Syrjänen, 2008). While the project is being managed and executed by the Government of Kenya, the UN-Habitat, civil society organizations, private sector, the affected community, and other relevant actors complement and support their efforts with, UN-Habitat specifically providing technical assistance and consultancy through UN volunteers, also assist with financial and other resource mobilization by liaising with donors (Anderson \& Mwelu, 2013; Syrjänen, 2008). The government estimates that the project would improve the lives of 5.3 million urban slum dwellers by 2020 at a cost of Kshs 884 billion or $\$ 13$ billion (Anderson \& Mwelu, 2013). The initial funding for the project would come from the Cities Alliance and the UN-Habitat at USD 240,000 and USD 110,000, respectively. The Pilot project for KENSUP was initiated in Kibera, the biggest slum in Kenya going by population and located on 225-hectare piece of land, 5 kilometers away from Nairobi City Centre (Syagga, Mitullah, \& Gitau, 2001). According to GOK (2019a), the population of Kibera is 185,777 far below the estimations by many previous studies which put it between 170,000 and 1 million, making it the biggest slum in Kenya (Ogundele, 2014). The project focused on Soweto, one of the 12 villages in Kibera including Gichinjio, Kisumu Ndogo, Mashimoni, Silanga, Makina, Soweto East, Kianda, Raila, Lindi, Soweto West, Laini Saba and Gatuikira (MacDonald, 2014). 
Successful upgrading of Soweto East was pegged on successful relocation of 25,000 residents to a decanting site in Langata (nearby neighborhood), thereby creating room for the construction of new housing units and infrastructures (Amnesty International, 2009). A total of 1,200 households have since been relocated to the decanting site from Soweto, and the first phase of the project completed with 822 housing units having been constructed, of which, 691 units were allocated to the successfully vetted beneficiaries (GOK, 2020b). Necessary infrastructure in the area was also provided beside the construction of a 0.5 kilometers access road in Soweto (Hakijamii, 2015). The KENSUP, however, failed to integrate four of the 12 basic principles of slum upgrading outlined by the UN-Habitat. According to UN-Habitat (2015), slum upgrading should be: People-centred by aiming to lift the slum residents from poverty and not just focusing on physical aspects of the slums, participatory and involve the members of the public and other stakeholders, address the land issue to provide the slum residents with security of tenure, combine slum upgrading with employment generating activities and also invest on the social capitals existing to improve cohesiveness. Amnesty International (2009) established from their interviews with the residents that there wasn't consultation on the design and location of the relocation sites which was far from the slum area thus cutting them off from their daily income activities and destroying the social networks that existed between neighbors. More than half of the families relocated also moved back to the slums while selling or renting their new homes citing affordability of the new houses and insufficient information (Amnesty International, 2009; Kajilwa, 2017a).

Slum Upgrading in Kenya is also implemented through the Kenya Informal Settlement Improvement Project (KISIP). Just like KENSUP, it is a collaboration between Kenyan Government and international development agencies; The World Bank, the Agence Française de Dévelopement (AFD) and the Swedish International Development Cooperation Agency (SIDA) who jointly initiated the program in 2011(GOK, 2020a). According to Anderson and Mwelu (2013), the cost of KISIP projects was shared by the Kenyan Government (10\%), World Bank (60\%), SIDA and AFD (30\%). The program intended to address the slum problem of land tenure security and improve the living condition of slum dwellers through income-generating activities. The main weakness of the program is the top-down approach to development it adopted by excluding the civil societies and not involving members of the public fully in the implementation (Anderson \& Mwelu, 2013).

\section{Policy, Legal and Institutional Efforts}

The Kenyan Government has sought to address the housing crisis through legislations, policies and establishment of institutions meant to implement them. After independence, the government embarked on addressing the housing shortage and slum problems through The 
Sessional Paper No.5 which became the first comprehensive National Housing policy for Kenya. The policy required the government to take steps to provide adequate shelters to the citizens and offset the housing shortage of 7,600 and 38,000 per annum in rural and urban areas respectively (ROK, 2004). The policy created the National Housing Cooperation (NHC) in charge of low cost and civil servants housing construction, besides utilization of government and donor funds for housing. The National Housing Policy has since been updated to reflect the increasing demand for affordable housing and slum and informal settlements proliferation through the formulation of Sessional Paper No.3 of 2004, National Housing Policy for Kenya. With an annual housing unit production of 20,000-30,000 and demand of 150,000, Kenya has an acute shortage of housing causing many to live in informal settlements (ROK, 2004). The updated policy, therefore, seeks to narrow this gap in production.

The Vison 2030 formulated in 2008 is also a long-term plan intended to transform Kenya into an industrializing middle-income country by 2030, by addressing among others the housing shortage (Matanga, 2015). In a short term plan, the policy intended to increase the annual housing output from 35,000 to 200, 000 by 2012 and increase the accessibility of housing mortgage among Kenyans by establishing a secondary mortgage finance corporation and National Housing Fund (Mwenzwa \& Misati, 2014). The targets set by the Vision 2030 are set to be fast-tracked by Big four Action Plan, delivering a record 500,000 lowcost affordable houses across 47 counties of Kenya between 2017 and 2022 (Presidency, 2017). Through this policy, the government established the Kenya Mortgage Refinance Company (KMRC), jointly owned by Kenyan Government and commercial banks and whose goal is to lend mortgage to aspiring homeowners at a reduced interest rates of a single-digit value and an extended repayment period of more than 20 years from the 7 years (Kimanthi, 2018). This policy also intends to lower the housing deficit gap among middle and low-income earners by $60 \%$ from the current deficit of $95 \%$ by lowering homeownership and construction cost by $50 \%$ and $30 \%$ respectively (Presidency, 2017).

The implementation of these policies was necessitated by the formation of various institutions. The Ministry of Transport, Infrastructure, Housing, Urban Development, and Public Works is responsible for formulation of and implementation policies for sustainable housing and urban development and currently undertaking the construction of 500,000 affordable houses, slum upgrading, civil servant housing schemes and setting construction and building standard (GOK, 2017). National Housing Corporation is also mandated to undertake the construction of low-cost houses and do housing research. The corporation builds decent housing in Kenya through Outright Sale, Tenant Purchase, Rural and Peri-Urban Housing Loans and Rental Housing (GOK, 2020c). The Civil Servants Housing Scheme Fund (CSHSF) another institution entrusted to implement the housing policies 
was formed in 2004 as part of the implementation of National Housing Policy (2004) which required employers to support their employees to acquire housing(GOK, 2019b). The institution has since enabled more than 3000 civil servants to access housing through the provision of housing loans and sale of residential units and 600 others have been able to purchase or construct homes through loans provided by the scheme. Finally, the Kenya Mortgage Refinance Company (KMRC) which is a government-private financial institution was formed to offer cheaper loans so that more Kenyans can buy homes. The sole function of the KMRC is to provide cheap long-term loans to primary mortgage lenders like banks and microfinance banks who can then lend to Kenyans a cheaper mortgage (PSCU, 2019).

Table 1: The housing policy and institutional framework

\begin{tabular}{|l|l|}
\hline $\begin{array}{l}\text { Policies and Implementation } \\
\text { Bodies }\end{array}$ & \multicolumn{1}{|c|}{ Roles } \\
\hline National Housing Policy & $\begin{array}{l}\text { Construction of affordable housing and } \\
\text { slum clearance. }\end{array}$ \\
\hline Vison 2030 & $\begin{array}{l}\text { Reduce housing shortage by raising annual } \\
\text { output from 35,000 to 200,000. }\end{array}$ \\
\hline Big four Action Plan & $\begin{array}{l}\text { Provision of 500,000 affordable houses to } \\
\text { Kenya by 2022. }\end{array}$ \\
\hline Ministry in charge of Housing & Housing Policy formulation \\
\hline National Housing Corporation & $\begin{array}{l}\text { Construct affordable and decent houses for } \\
\text { Kenyans. }\end{array}$ \\
\hline Civil Servants Housing Scheme Fund & $\begin{array}{l}\text { Enable civil servants buy or construct } \\
\text { homes. }\end{array}$ \\
\hline Kenya Mortgage Refinance Company & $\begin{array}{l}\text { Offer cheaper loans for Kenyans to buy } \\
\text { homes. }\end{array}$ \\
\hline
\end{tabular}

\section{KEY CHALLENGES TO HOUSING POLICIES IMPLEMENTATION EFFORTS}

Efforts to address housing problems in Kenya though measures like slum upgrading have encountered numerous challenges. Lack of land tenure security which is common in the slums is a major issue that should be looked into for successful slum upgrading. The process should also be conducted in a legal and humanitarian manner to avoid legal hurdles and victimization of the residents. Legitimacy and viability of the project also depend on the level of involvement of stakeholders as discussed in this section.

\section{Land Tenure Problems in Slums}

Nairobi, the capital city of Kenya has more than 260 slums that host more than 2 million people and account for less than $5 \%$ of the total residential land in the city (Amnesty International, 2009). Despite attempts to raise the living conditions in the slums, there still exists a disparity between the formal and informal settlements in Nairobi in terms of access to basic services like infrastructures and housing 
(Talukdar, 2018). Inadequate sanitation and unhygienic methods of waste disposal in the slums have exposed slum residents to dangerous diseases and sanitation-related problems. In 2002, a study revealed that among children below 5 years of age and living in slums, the prevalence of diarrhea at $32 \%$ was more than double the rate for Nairobi and the entire country average (Kimani-Murage \& Ngindu, 2007). Hanchett, Akhter, Khan, Mezulianik, and Blagbrough (2003) attribute the use of unhygienic means like pit latrines, hanging latrines, and open spaces for human wastes disposal to inadequate provision of sanitation facilities in the slums. In Kibera, high population density, poverty, and inadequate provision of sanitation has led to the overusing of latrines, in some instances more than 200 people sharing a single latrine (Schouten \& Mathenge, 2010). The situation is similar in Mathare Slums of Nairobi where an average of 85 households share a single toilet, and on average a household must cover a distance of 52 meters to access the toilet. Consequently, poor health is reported among $83 \%$ of the household without private toilets in Mathare slums (Corburn \& Hildebrand, 2015). Inadequate access to clean water for drinking is another major deprivation among the slum dwellers in Kenya. In their survey about access to water in informal settlements, UN Human Rights (2020) reported that more than $35 \%$ of slum residents in Nairobi takes more than 30 minutes to access water due to few water points. Besides, the poor conditions of water and sewerage lines often results into water contamination, thus, leading to high incidences of water-borne diseases like cholera. Water inadequacy in the informal settlements also means that households in the slums pay up to 50 times the price of water per liter than middle class household in the formal settlements.

Housing is similarly in poor state in slums compared to other formal parts of Nairobi. According to Bird, Montebruno, and Regan (2017), only $24 \%$ of slum dwellers live in structures with solid walls while the number is quite high in the formal settlements of Nairobi (84\%). In most cases, the wall structures in slums are made of corrugated iron sheets or mud. Overcrowding is also a major problem experienced in the slums. Whereas close to $60 \%$ of the Nairobi population live in the informal settlements, the slums only occupy about $6 \%$ of the total city land. The tiny $12 \mathrm{ft}$ by $12 \mathrm{ft}$ structures in the slums hosts families of eight or more, with many sleeping on the floors (Onyango \& Tostensen, 2015). Just like other basic services, access to primary health facilities in the slums is also a major challenge. A study in three major slums of Nairobi. i.e. Kibera, Viwandani and Korogocho revealed that access to public health services was very low among the slum communities due to the existence of few public health facilities. It was determined that only $1 \%$ of the health facilities were public, $16 \%$ were private non-profiting while $83 \%$ were private-for-profit facilities (UNICEF, 2012). Considering the high cost of treatment in private facilities and the low-income levels among the slum communities, the lack of access to health services is major threat to their health. 
A major factor contributing to poor infrastructural investment by tenants and property owners in the slums is the absence of secure land and property rights (Kim, Yoon, \& Mutinda, 2019). Nakamura (2017) also argues that lack of secure land tenure discourages able slum residents from self-help housing constructions due to risks of forceful eviction or demolition of properties. In Kenya, most of the slums are built on public lands. Lack of land tenure security has exposed slum tenants and dwellers to constant threats of eviction and demolition of their properties thus hampering any meaningful housing and infrastructural investments. Syagga (2011) argues that security of tenure guarantees one legal protection against such threats of evictions, harassment, and arbitrary deprivation of one's property.

\section{Poor Public Participation}

Community involvement in the implementation of projects is very crucial in ensuring that projects are successfully implemented, and lack of it has often led to the failure of projects (Abatena, 1997). It is important to involve members of the public at all stages of the project like problem identification and the project execution/implementation. Anderson and Mwelu (2013) identified inadequate involvement of slum residents in the implementation of KENSUP and KISIP projects as one of the key challenges. Instead, the ministry involved adopted a top-down approach in decision making without adequately involving the public and the civil societies despite stressing otherwise. Insufficient consultation with the residents was also reflected on the decision by more than half the residents who deserted the new houses and moved back to slums citing inability to afford the new houses, distance of the new sites from their main areas of economic activities, social relation problems (Amnesty International, 2009; Kajilwa, 2017b). Projects like slum upgrading, social housing and, affordable housing are targeting the middle and low incoming earners, who need to be involved in the specific details about the projects that have the potential to hugely impact their daily lives.

\section{Legal Challenges}

Implementation of development projects often faces legal challenges that affect the duration of implementation or even realization. Noncompliance with the rights of the stakeholders in a project, and the rules and regulation guiding development are some of the reasons that may affect the completion of a project. Even in cases where the residents of a slum lack the land tenure security, the international human rights is against demolition and forceful eviction, which should be a means of last resort after alternative ways of solving the problem like consultation have been explored (Amnesty International, 2009). While Kenyan laws do not expressly prohibit forceful eviction, the high courts have issued court injunctions again eviction of slum residents for development projects as was the case with the railway project in Kibera. This happens 
especially when there is no adequate notice served on residents prior to eviction, no compensation offered and no efforts made to find alternative places for resettlement of those affected (Amnesty International, 2009). Court injunctions delay the implementation of projects and may have huge cost implications. The law of eminent domain, which according to Lai (2014) empowers the government to confiscate private properties for public use and interest upon compensation, has been misapplied by authorities to forcefully grab slums without resettling the residents. While the residents may lack the security of tenure as they don't legally own the land, the Kenyan constitution calls for compensation in good faith to people who are not the rightful owners of land but have been occupying it for a period of time (GOK, 2010b).

\section{CONCLUSION AND SUGGESTIONS}

While important steps have been taken to address the housing deficit and its manifestation in the form of slums in Kenya, more need to be done to find answers to land tenure security problems, public participation, socio-economic and infrastructural deprivations, and legal challenges that delay the implementation efforts of housing policies. Slum upgrading has wildly been accepted as a more humane and efficient way of responding to poor conditions in the slums as opposed to previous efforts like forceful evictions that destroyed properties. The upgrading process must however not just focus on the physical aspects of the slums like housing and infrastructures, but also address the social and economic issues like unemployment and community cohesiveness within the slum.

Based on the analysis of available data from the secondary sources, the study suggests several actions to improve the effectiveness of urban housing intervention efforts by the government and policymakers. The study identifies socioeconomic and infrastructural deprivation, insufficient public participation in critical decision-making processes, the illegal status and legitimacy of informal settlements, and gaps in the law as the main challenges to finding the solution to urban housing problems in Kenya, especially in the informal settlements. Firstly, there is evidence of socio-economic and infrastructural deprivations in the informal settlements when compared with the formal parts of Nairobi. Efforts must therefore not be limited to addressing the housing problems but also poverty elimination in the slums. The study established an imbalance in distribution and allocation of basic services like health facilities, water, and sanitation among others, thus affecting accessibility and raising the cost for slum residents using the services. This contributes to slum poverty. It is therefore recommended that provision of the basic services be carried out in the slums alongside and economic empowerment programs to relieve the residents of financial poverty. Slum upgrading programs should therefore seek to impact the socio-economic lives of the slum dwellers. 
Secondly, the study reveals that most slum residents lack land tenure security because they don't own the lands. This has contributed to the dire state of slums in Kenya i.e. untarmacked roads, lack of sidewalks, inadequate provision of sewerage systems, poor housing conditions, poor electric connections etc. In the study, it has also been revealed that the illegal status of the slums has caused successive governments to neglect them by not providing essential services, thus contributing to the poor conditions. Provision of important infrastructures by developers requires a long-term certainty about the security of the investment without fear of eviction or demolition. It is recommended that necessary documents like title deeds be issued to the slum dwellers and developers to legitimize these informal settlements and consequently encourage infrastructural investments through assured security.

Thirdly, although there was evidence of public participation in the projects carried out by the government to upgrade the informal settlements, the level of involvement is determined to be insufficient and, in some instances, the decisions were made at the top with less community contribution. Involving slum residents is particularly significant in slum upgrading programs because of the direct impact it has on the residents' mobility, social cohesiveness, economic disruption, and financial expenditures. Abandonment of almost half of the newly constructed building by KENSUP exposed the danger of a decisionmaking process that does not avail adequate information to members of the public. A bottom-up approach to slum upgrading is therefore recommended to ensure that the views of slum dwellers regarding their need priorities, and satisfaction are considered. This would also boost projects' legitimacy by ensuring that they are accepted and utilized as intended.

Finally, while the development of informal settlements is mainly blamed on failed housing policies in urban areas, this study shows that noncompliance with the construction regulations plays a role in the emergence of substandard buildings in the city. Insufficient enforcement of planning rules and regulations by the authorities also contributes enormously to the growth of slums in the city. Full compliance and enforcement of existing policies, rules, and regulations are therefore proposed to stop further deterioration of housing conditions in Nairobi and other urban areas. Implementation of slum upgrading through evictions, demolitions, and relocations must however be done in a way that respects the dignity of slum residents and in line with both national and international laws of justice.

\section{ACKNOWLEDGMENT}

This article was firstly presented at the ICONARC IV congress. It was selected by the congress science committee for the ICONARP Special Issue. We thank the referees for their valuable contribution to the ICONARCH congress and ICONARP special issue process. 
Challenges to Urban Housing Policies Implementation Efforts: The Case of Nairobi, Kenya

\section{CONFLICT OF INTEREST}

We declare that the study has no conflict of interest. We confirm that this work is original and has not been published elsewhere nor is it currently under consideration for publication elsewhere.

\section{FINANCIAL DISCLOSURE}

This study has received no financial support anywhere.

\section{ETHICS COMMITTEE APPROVAL}

The ethics committee approval was not required for this article.

\section{LEGAL PUBLIC/PRIVATE PERMISSIONS}

The legal public/private permissions was not required for our paper.

\section{REFERENCES}

Abatena, H. (1997). The significance of planned community participation in problem solving and developing a viable community capability, Journal of Community Practice, 4(2), 13-34.

Agayi, C. 0., \& Karakayacı, Ö. (2020). The Role of Changing Housing Policies in Housing Affordability and Accessibility in Developing Countries: The Case of Kenya, Journal of Contemporary Urban Affairs, 4(2), 49-58.

Amnesty International (2009). Kenya: The Unseen Majority: Nairobi's Two Million Slum-Dwellers, Amnesty International Publications. https://www.amnesty.org/download/Documents/44000/afr32005200 9eng.pdf

Anderson, M., \& Mwelu, K. (2013). Kenyan Slum Upgrading Programs: KISIP \& KENSUP, UC Berkeley Center for Global Healthy Cities. https://static1.squarespace.com/static/58d4504db8a79b27eb388c91/ t/58e686c23a0411e265af3783/1491502788579/2013_KENYAN_SLUM _UPGRADING_PROGRAMS_ANDERSON_MWELU.pdf

$\mathrm{Au}, \mathrm{C}$.-C., \& Henderson, J. V. (2006). How migration restrictions limit agglomeration and productivity in China, Journal of Development Economics, 80(2), 350-388.

Barnow, N. F., Hansen, N. W., Johnsen, M., Poulsen, A., Rønnow, V., \& Sølvsten, K. (1983). Urban Development in Kenya: The Growth of Nairobi 1900-1970, Kunstakademiets Arkitektskole, Institut 1.

Bird, J., Montebruno, P., \& Regan, T. (2017). Life in a slum: understanding living conditions in Nairobi's slums across time and space, Oxford Review of Economic Policy, 33(3), 496-520

Chan, K. W., \& Buckingham, W. (2008). Is China abolishing the hukou system? The China Quarterly, 195, 582-606.

Corburn, J. (2013). Healthy City Planning: From Neighbourhood to National Health Equity. Routledge.

Corburn, J., \& Hildebrand, C. (2015). Slum sanitation and the social determinants of women's health in Nairobi, Kenya, Journal of Environmental and Public Health, 2015, 1-6. 
Everett, M. (2001). Evictions and human rights: land disputes in Bogotá, Colombia, Habitat International, 25(4), 453-471. doi:https://doi.org/10.1016/S0197-3975(01)00015-7

GOK. (2010a). The 2009 Kenya population and housing census (Vol. 1). Kenya National Bureau of Statistics.

GOK. (2010b). Constitution of Kenya, 2010. Nairobi: Government Printer. http://kenyalaw.org/lex/rest/db/kenyalex/Kenya/The\%20Constitutio n\%20of\%20Kenya/docs/ConstitutionofKenya\%202010.pdf.

GOK. (2017). Ministry of transport, infrastructure, housing and urban development - service charter. Nairobi: Government Printer.

GOK. (2019a). Kenya population and housing censusvolume i: Population by county and sub county. Nairobi: Government Printer. https://www.knbs.or.ke/?wpdmpro=2019-kenya-population-andhousing-census-volume-i-population-by-county-and-sub-county.

GOK. (2019b). The Civil Servants Housing Scheme Fund (CSHSF). http://www.housingandurban.go.ke/project/porto-building/

GOK. (2020a). The Kenya Informal Settlement Improvement Project (KISIP). https://www.housingandurban.go.ke/project/jet-hotels/

GOK. (2020b). Kenya Slum Upgrading Programme (KENSUP): Key milestones. $\quad$ https://www.housingandurban.go.ke/kenya-slumupgrading-programme-kensup/

GOK. (2020c). The National Housing Corporation. https://www.nhckenya.co.ke/index.php?option=com_content\&view=ar ticle\&id=218\&lang=en

Hakijamii. (2015). Slum upgrading manual-May 2015. Nairobi.

Hanchett, S., Akhter, S., Khan, M. H., Mezulianik, S., \& Blagbrough, V. (2003). Water, sanitation and hygiene in Bangladeshi slums: an evaluation of the WaterAid-Bangladesh urban programme, Environment and Urbanization, 15(2), 43-56.

Hay, A., \& Harris, R. (2007). 'Shauri ya Sera Kali': the colonial regime of urban housing in Kenya to 1939, Urban History, 34(3), 504-530.

Home, R. (2012). Colonial township laws and urban governance in Kenya, Journal of African Law, 56(2), 175-193.

Kajilwa, G. (2017a). Why Kibera residents opted to give out new houses. Standard Digital.

https://www.standardmedia.co.ke/article/2001252370/why-kiberaresidents-opted-to-give-out-new-houses

Kajilwa, G. (2017b). Why Kibera residents opted to give out new houses. The Standard.

https://www.standardmedia.co.ke/article/2001252370/why-kiberaresidents-opted-to-give-out-new-houses

Kamete, A. Y. (2009). In the Service of Tyranny: Debating the Role of Planning in Zimbabwe's UrbanClean-up'Operation, Urban Studies, 46(4), 897-922. 
Kim, H.-S., Yoon, Y., \& Mutinda, M. (2019). Secure land tenure for urban slum-dwellers: A conjoint experiment in Kenya, Habitat International, 93, 1-14.

Kimani-Murage, E. W., \& Ngindu, A. M. (2007). Quality of water the slum dwellers use: the case of a Kenyan slum, Journal of Urban Health, 84(6), 829-838.

Kimanthi, K. (2018). Uhuru Kenyatta outlines 'Big Four' progress. Daily Nation, December 13 2018. https://www.nation.co.ke/news/UhuruKenyatta-outlines-big-four/1056-4893040-14u1vl6/index.html

Kingoriah, G. K., (1983). The causes of Nairobi's city structure. Ekistics,, 50(301), 246-254.

Lai, L. W. (2014). Private property rights not to use, earn from or trade land in urban planning and development: A meeting between Coase and Buchanan, Habitat International, 44, 555-560.

MacDonald, M. (2014). Community Perception of Slum Upgrading Initiatives in Soweto East, Kibera (Nairobi, Kenya). McGill University Libraries.

Macharia, K. (1992). Slum clearance and the informal economy in Nairobi, The Journal of Modern African Studies, 30(2), 221-236.

Matanga, B. O. (2015). Implementing the right to housing for residents of slums and informal settlements in Kenya: Legal, policy and institutional challenges and prospects. [Master's thesis, University of Nairobi, School of Law]. University of Nairobi Library.

Minnery, J., Argo, T., Winarso, H., Hau, D., Veneracion, C. C., Forbes, D., \& Childs, I. (2013). Slum upgrading and urban governance: Case studies in three South East Asian cities, Habitat international, 39, 162-169.

Mitullah, W. V. (1993). State policy and urban housing in Kenya: the case of low income housing in Nairobi. University of York.

Muchadenyika, D., \& Waiswa, J. (2018). Policy, politics and leadership in slum upgrading: A comparative analysis of Harare and Kampala, Cities, $82,58-67$.

Muraguri, L. (2011). Kenyan government initiatives in slum upgrading, Les Cahiers d'Afrique de l'Est/The East African Review, 44, 119-127.

Mwenzwa, E. M., \& Misati, J. A. (2014). Kenya's Social Development Proposals and Challenges: Review of Kenya Vision 2030 First MediumTerm Plan, 2008-2012, American International Journal of Contemporary Research, 4(1), 246-253.

Nakamura, S. (2017). Does slum formalisation without title provision stimulate housing improvement? A case of slum declaration in Pune, India, Urban Studies, 54(7), 1715-1735.

Obudho, R., \& Aduwo, G. (1989). Slum and squatter settlements in urban centres of Kenya: Towards a planning strategy, The Netherlands Journal of Housing and Environmental Research,4, 17-29.

Ogilvie, G. C. (1946). The housing of Africans in the urban areas of Kenya. Kenya Information Office. 
Ogundele, A. (2014). Decanting and Social Sustainability: Kenya Slum Upgrading Programme (A Case Study). University of Waterloo.

Olthuis, K., Benni, J., Eichwede, K., \& Zevenbergen, C. (2015). Slum Upgrading: Assessing the importance of location and a plea for a spatial approach. Habitat international, 50, 270-288.

Onyango, P., \& Tostensen, A. (2015). The Situation of youth and children in Kibera, CMI Report, (3).

Otiso, K. M. (2002). Forced evictions in Kenyan cities, Singapore Journal of Tropical Geography, 23(3), 252-267.

Otiso, K. M. (2005). Colonial urbanization and urban management in Keny. In S. J. Salm, T. Falola (Eds.). African Urban Spaces in Historical Perspective (pp.73-97). University of Rochester Press.

Schouten, M., \& Mathenge, R. (2010). Communal sanitation alternatives for slums: A case study of Kibera, Kenya, Physics and Chemistry of the Earth, Parts A/B/C, 35(13-14), 815-822.

Presidency, T. (2017). The Big Four: Affordable Housing. http://www.president.go.ke/affordable-housing/

PSCU. (2019). Mortgage refinance company to boost affordable housing agenda - Uhuru. The Star. https://www.the-star.co.ke/news/2019-0523-refinance-company-to-provide-mortgages/

Reuters. (2018). Slums demolished for new Kenyan road. https://www.reuters.com/news/picture/slums-demolished-for-newkenyan-road-idUSRTX6CG6R

ROK. (2004). Sessional Paper No.3 of 2004 on National Housing Policy for Kenya. Nairobi: Government Printer. http://www.mintoreal.com/policydocuments/kenya-national-housing-policy?download=8:kenyanational-housing-policy.

Sulemana, I., Nketiah-Amponsah, E., Codjoe, E. A., \& Andoh, J. A. N. (2019). Urbanization and income inequality in Sub-Saharan Africa, Sustainable Cities and Society, 48, 101544.

Syagga, P. (2011). Land tenure in slum upgrading projects, Les cahiers d'Afrique de l'est, 103-113.

Syagga, P. M., Mitullah, W. V., \& Gitau, S. K. (2001). Nairobi situation analysis. Government of Kenya and UNCHS Collaborative Nairobi Slum Upgrading Initiative, Nairobi.

Syrjänen, R. (2008). UN-Habitat and the Kenya slum upgrading programme: strategy document: United Nations Human Settlements Programme.

Talukdar, D. (2018). Cost of being a slum dweller in Nairobi: Living under dismal conditions but still paying a housing rent premium, World Development, 109, 42-56.

UN. (2014). World urbanization prospects: The 2014 revision, highlights. United Nations Department of Economic and Social Affairs, Population Division, Methodology Working Paper No. ESA/P/WP.238.

UN-Habitat (2003). The challenge of slums: global report on human settlements, 2003. United Nations Human Settlements Programme 
Challenges to Urban Housing Policies Implementation Efforts: The Case of Nairobi, Kenya

UN-Habitat (2015). Slum Almanac 2015/2016 :Tracking Improvement in the Lives of Slum Dwellers. https://unhabitat.org/wpcontent/uploads/2016/02-old/Slum\%20Almanac\%202015-

2016_EN.pdf

UN-Habitat (2016). Slums Almanac 2015-16: Tracking Improvement in the Lives of Slum Dwellers.

UN Human Rights (2020). Kenya's informal settlements need safe water to survive

COVID-19. https://www.ohchr.org/EN/NewsEvents/Pages/COVID19_RighttoWate rKenya.aspx

UNICEF. (2012). The State of The World's Children 2012: Children in An Urban World. In Focus on-Maternal and Child Health Services for the Urban Poor. A case Study of Kenya. New York.

Wafula, N. (2004). Affordable housing in Kenya: A case study of policy on informal settlements. 3rd FIG Regional Conference Jakarta, 3-7 October 2004, Indonesia.

\section{Resume}

Collins Ouma Agayi holds a Bachelor of Urban and Regional Planning degree which he was awarded by the University of Nairobi, Nairobi, Kenya, and a Master of City and Regional Planning which he received from Selcuk University in Turkey. He is currently pursuing a Ph.D. in city and Regional Planning at Konya Technical University in Turkey. His research interests include housing and human settlement, regional development, and rural poverty.

Özer Karakayacl; (B.Arch, M.Sc., PhD.) He received his B.Arch and MSc. in City and Regional Planning from Selcuk University, Faculty of Architecture (1996-2003). He earned his PhD. degree in Regional Planning from Yildiz Technical University (2011). He is currently working as an Assoc. Prof. at Konya Technical University. Major research interests include regional planning, economic geography, social capital, industrial geography, and rural planning. 